\title{
Nieznana relacja Kazimierza Świtalskiego na temat zamachu majowego
}

Wydarzenia, w których wyniku władzę w państwie przejął Józef Piłsudski, do dzisiaj budzą zainteresowanie historyków. Świadczą o tym nie tylko nowe opracowania poświęcone temu zagadnieniu ${ }^{1}$, lecz także liczne zbiory dokumentów opublikowane w ostatnich latach ${ }^{2}$. Wiele aspektów dokonanego wówczas przewrotu wojskowego, w dalszym ciągu czeka jednak na swoje ostateczne wyjaśnienie. Warto więc zwrócić uwagę na nieznaną dotychczas relację źródłową, tym bardziej że pochodzi ona od jednego z najbliższych współpracowników Józefa Piłsudskiego.

Jej autorem jest Kazimierz Świtalski, polityk, który już w okresie poprzedzającym zamach majowy z 1926 r. należał do ścisłego kierownictwa obozu piłsudczykowskiego, a w późniejszych latach pełnił najwyższe funkcje w państwie. W czerwcu 1928 r. otrzymał nominację na premiera, a niespełna rok później sam stanął na czele rządu. Natomiast w latach 1930-1935 sprawował urząd marszałka Sejmu III kadencji ${ }^{3}$. Nie jest to jedyna jego relacja dotycząca ówczesnych wypadków, ponieważ informacje o nich można także odnaleźć w prowadzonych przez niego prywatnych zapiskach, wydanych po latach drukiem w formie diariusza ${ }^{4}$. W notatce, sporządzonej prawdopodobnie tuż po zakończeniu walk, Świtalski stwierdził, iż ostateczna decyzja o marszu na Warszawę została przez Piłsudskiego podjęta pod wpływem konfiskaty jego wywiadu dla „Kuriera Porannego” oraz wcześniejszego utworzenia rządu „Chjeno-Piasta”. O tym, że miała to być jedynie demonstracja zbrojna, świadczy zdaniem autora fakt, iż Marszałek ,podporządkowywał sobie garnizon rembertowski

\footnotetext{
${ }^{1}$ Zamach stanu Józefa Pitsudskiego 1926 roku, red. M. Sioma, Lublin 2007; Zamach stanu Józefa Pitsudskiego i jego konsekwencje w interpretacjach polskiej myśli politycznej XX wieku, red. Z. Karpus, G. Radomski, W. Wojdyło, Toruń 2008; P. Olstowski, Generat Gustaw Orlicz-Dreszer jako realizator przewrotu majowego, „Niepodległość” 2011, t. LX, s. 7-35; P. Duber, Z genezy przewrotu majowego, „Niepodległość” 2012, t. LXI, s. 295-302; M. Wołos, O Pitsudskim, Dmowskim i zamachu majowym. Dyplomacja sowiecka wobec Polski w okresie kryzysu politycznego 1925-1926, Kraków 2013.

2 Z. Cieślikowski, Zamach stanu. Materiaty źródtowe do przewrotu majowego, Warszawa 2002; Przewrót majowy 1926 r. $w$ relacjach świadków i uczestników. Materiaty Instytutu Józefa Pitsudskiego, red. A. Adamczyk, Londyn-Piotrków Trybunalski 2003; Majowy zamach stanu w świetle dokumentów wywiadu, dyplomacji i organów bezpieczeństwa II Rzeczypospolitej, red. P. Kołakowski, A. Pepłoński, Słupsk 2008.

${ }^{3}$ Por.: P. Duber, Działalność polityczna Kazimierza Świtalskiego w latach 1926-1939, Poznań 2013; R. Świętek, Kazimierz Świtalski, premier Rzeczypospolitej 14 IV-7 XII 1929, w: Prezydenci i premierzy Drugiej Rzeczypospolitej, red. A. Chojnowski, P. Wróbel, Wrocław 1992, s. 264-279.

${ }^{4}$ K. Świtalski, Diariusz 1919-1935, Warszawa 1992.
} 
w taki sposób, że musiało dowiedzieć się o tych krokach Ministerstwo Spraw Wojskowych" W późniejszych uzupełnieniach, włączonych przez wydawców do właściwej treści diariusza, podał kilka dodatkowych szczegółów na temat swojego udziału w tych przełomowych wydarzeniach, ograniczając się jednak przede wszystkim do informacji o wynikach spotkania z Adamem Kuryłowiczem, prezesem Związku Zawodowego Kolejarzy. Stwierdził także, iż cel, jaki postawił przed sobą Piłsudski, polegał w dużej mierze na opanowaniu siedziby Sztabu Generalnego, co miało stać się ważnym argumentem w dalszej walce o władzę. Świtalski sporządził również kilkustronicową notatkę, w której zawarł swój pogląd na temat genezy przewrotu majowego z uwzględnieniem m.in. ówczesnej sytuacji wewnętrznej państwa polskiego, szkodliwego wpływu rozgrywek politycznych na kondycję polskiej armii oraz trudnego położenia międzynarodowego ${ }^{6}$.

Publikowany dokument stanowi ważne uzupełnienie diariusza, mimo iż powstał w dosyć szczególnych okolicznościach. Jest to bowiem obszerny fragment zeznania złożonego przez Świtalskiego 27 VIII 1953 r. przed przesłuchującym go oficerem śledczym Ministerstwa Bezpieczeństwa Publicznego. Fakt ten skłania naturalnie do szczególnej ostrożności, ponieważ w podobnych przypadkach czynnikiem mającym duży wpływ na treść wypowiadanych słów był nie tylko upływ czasu, zacierający w pamięci wiele istotnych szczegółów, lecz także obawa przed represjami ze strony władz komunistycznych. Okazuje się jednak, że informacje przekazane przez tego byłego sanacyjnego polityka należy uznać za w pełni wiarygodne. Można się o tym przekonać, porównując je z innymi dostępnymi źródłami. Świtalski, przedstawiając genezę zamachu majowego, stwierdził, iż o planowanej demonstracji zbrojnej nie był wcześniej poinformowany, podobnie zresztą jak pozostali cywilni współpracownicy Marszałka. Fakt ten znajduje potwierdzenie we wspomnieniach uczestników ówczesnych wydarzeń ${ }^{7}$. Trudno się temu dziwić - ich zadanie polegało przecież na prowadzeniu działań o charakterze politycznym ${ }^{8}$. Świadczy o tym rozmowa z 15 XII 1925 r. Piłsudski, kreśląc przed autorem relacji scenariusz rozwoju wydarzeń na najbliższe miesiące, stwierdził: „Następne przesilenie rządowe starać się załatwić bez Sejmu. Dostać się do wojska. Pójść, zapewne w roli ministra spraw wojskowych, ostro i brutalnie przeciw Sejmowi. Sejmu nie rozwiązywać, a ograniczyć jego zbieranie się. Siedząc w gabinecie przypatrywać się jego członkom dla orientacji, z kim iść można - a z kim nie. Przyjść do władzy ewentualnie w jesieni 26 r." . We fragmencie tym nie znalazły się żadne informacje na temat ewentualnego przewrotu, choć w nadchodzących wypadkach wojsko miało niewątpliwie odegrać istotną rolę. Świtalski potwierdził te słowa w publikowanym poniżej dokumencie, zeznając, że Marszałek zamierzał opanować Sztab Generalny w celu obalenia rządu „Chjeno-Piasta”. Warto także zwrócić uwagę na fragment poświęcony wyborom prezydenckim, do których doszło 31 V 1926 r. Okazuje się, iż autor był wówczas łącznikiem pomiędzy Piłsudskim a popierającymi go ugrupowaniami politycznymi.

5 Ibidem, s. 184.

${ }^{6}$ Ibidem, s. $185-192$.

7 J. Grzędziński, Maj 1926, Paryż 1965, s. 16; S. Szwedowski, Dzieje ruchu zetowego w Polsce 1886-1945, Biblioteka Uniwersytetu Warszawskiego, sygn. 1745, k. 803; Przewrót majowy 1926 r. w relacjach świadków i uczestników. Materiały Instytutu Józefa Piłsudskiego, red. A. Adamczyk, Londyn-Piotrków Trybunalski 2003, s. 114; Autobiografia Leona Kozłowskiego zapisana w więzieniu na Łubiance, w: M. Kozłowski, Sprawa premiera Leona Kozłowskiego. Zdrajca czy ofiara?, Warszawa 2005, s. 219.

${ }^{8}$ J. Grzędziński, Maj..., s. 14.

${ }_{9}$ K. Świtalski, Diariusz..., s. 152. 
Oryginał tego dokumentu przechowywany jest wraz z innymi aktami procesowymi Świtalskiego w Archiwum Państwowym m.st. Warszawy ${ }^{10}$. Sporządzony został w formie rękopisu, w którym na każdej stronie widnieje podpis przesłuchiwanego. Przygotowując ten tekst do druku, starałem się w jak najmniejszym stopniu ingerować w jego treść, decydując się jedynie na pominięcie fragmentu opisującego znane powszechnie wydarzenia związane z przebiegiem przewrotu majowego. W przypisach zamieściłem objaśnienia podstawowych pojęć oraz biogramy wymienionych osób (z oczywistych względów pominąłem jedynie charakterystykę osoby Józefa Piłsudskiego). Wprowadziłem również kilka drobnych poprawek w pisowni nazwisk oraz nazw własnych.

\section{Pawel Duber}

Warszawa

\section{Protokół przesłuchania podejrzanego}

Bereś Henryk por. oficer śledczy Ministerstwa Bezpieczeństwa Publicznego w Warszawie przesłuchał w charakterze podejrzanego:

Świtalskiego Kazimierza

/dalsze personalia w aktach/

Przesłuchanie rozpoczęto o godz. 9:15

Pytanie: Opowiedzcie o przygotowaniach do przewrotu majowego 1926 r. przez grupę Piłsudskiego?

Odpow.: Okres 1918-1926 r. cechowała częsta zmiana rządów (przeciętnie co 7 miesięcy) i to rządów o różnym zabarwieniu i charakterze politycznym. Wynikało to ze względu na tworzenie się coraz to innych koalicji rządowych na terenie sejmowym. Ta niestałość rządów uniemożliwiała jakąkolwiek bądź politykę rządową stałą, jednolitą i konsekwentną.

Ponieważ Piłsudski oceniał sytuację Państwa Polskiego wskutek jego geograficzno-politycznego położenia za bardzo trudną, chciał zmianę stosunków w tym kierunku dokonać by mógł być Rząd bardziej trwały uważając, że w ten sposób wzmocni siłę Państwa Polskiego. Przy słabości ówczesnych stronnictw politycznych Piłsudski uważał że partie polityczne będą szukały swego wzmocnienia przez zjednywanie sobie wśród wyższych oficerów zwolenników tej czy innej Partii, co zagrażało jednolitości wojska polskiego pod względem organizacyjnym. Za środek prowadzący do usunięcia tego stanu rzeczy uznał Piłsudski marsz oddziałów wojskowych stacjonujących w pobliżu Warszawy lub w jej obrębie w kierunku gmachu Sztabu Generalnego i w ten sposób przejąć funkcję Szefa Sztabu, opanowując i obejmując wojsko w swoje ręce. Spodziewał się że po dokonaniu tego faktu Rząd tak zwanego Chjeno-Piasta ${ }^{11}$

\footnotetext{
${ }^{10}$ Archiwum Państwowe m.st. Warszawy, Sąd Wojewódzki dla m.st. Warszawy, sygn. IV 3K 14/54, t. II, Protokół przesłuchania podejrzanego K. Świtalskiego z 27 sierpnia 1953 r., k. 78-82.

${ }^{11}$ Rząd centroprawicowy z Wincentym Witosem na czele, powołany $10 \mathrm{~V} 1926 \mathrm{r}$. Popierany był przez Związek Ludowo-Narodowy, Chrześcijańską Demokrację, PSL „Piast” oraz Narodową Partię Robotniczą. Istniał zaledwie pięć dni i upadł w wyniku przejęcia władzy w państwie przez Józefa Piłsudskiego w drodze zamachu stanu.
} 
$\mathrm{z}$ Witosem ${ }^{12}$ na czele będzie musiał się podać do dymisji, a on przez ugruntowanie swoich wpływów w wojsku stanie się na nowo czynnikiem polityczno-wojskowym, który będzie mógł wpływać na dalszy bieg polityki w Państwie. Rząd Witosa (Chieno-Piasta) Piłsudski uważał zarówno za niestały, jak i za rząd który będzie musiał wywołać ostre fermenty polityczno-społeczne ze strony partii lewicowych, które uważały ten gabinet za prowokacyjny.

Czynności przygotowawcze do marszu oddziałów wojskowych w kierunku gmachu Sztabu Generalnego były robione przez Piłsudskiego przez osobiste zetknięcie się z dowódcami tych formacji w sposób poufny $\mathrm{z}$ uwagi na to, że Piłsudski wówczas żadnej władzy formalnej nad wojskiem nie posiadał. Polecenia jego były przyjmowane przez dowódców tych formacji na skutek uznawania przez nich autorytetu moralnego jego jako byłego ich Naczelnego Wodza. Jako osoba wówczas nie wojskowa ani o tych przygotowaniach ani o dacie marszu nie byłem uprzednio poinformowany zarówno przez samego Piłsudskiego jak i przez jego zwolenników z osób wojskowych. Mam pewność że Piłsudski o przygotowaniach w/w nie mówił z żadnymi osobami nie wojskowymi, bo znając charakter Piłsudskiego wiedziałem, że w takich wypadkach ograniczał się do informowania tylko tych osób, które miały brać w akcji udział bezpośredni. Żadnych innych czynności przygotowawczych Piłsudskiego i jego zwolenników nie było.

$[\ldots]$

Pytanie: Jaki był wasz udział w przewrocie majowym 1926 r.?

Odpow.: Jako osoba cywilna nie brałem czynnego udziału w walkach ulicznych w czasie zajść majowych 1926 r.

O terminie marszu Piłsudskiego na Warszawę nie byłem zawiadomiony i o rozpoczęciu akcji dowiedziałem się telefonicznie od ppłk. Wieniawy ${ }^{13} \mathrm{w}$ pierwszym jej dniu. Mimo że przed wypadkami majowymi Piłsudski w tym okresie czasu kiedy mieszkał w Sulejówku przyjeżdżając do Warszawy zachodził do mego mieszkania jednak o zamierzonym marszu nie wspominał mi. Rozmawiając telefonicznie z ppłk. Wieniawą-Długoszowskim dowiedziałem się o miejscu pobytu Piłsudskiego i udałem się tam. W/g oświadczenia ppłk. WieniawyDługoszowskiego Piłsudski znajdował się wówczas w dowództwie 36 p.p. stacjonującego na Pradze. Udając się w tamtym kierunku spotkałem na moście Kierbedzia Piłsudskiego w towarzystwie przybocznego oficera. Ppłk. Wieniawa Długoszowski powiadamiając mnie telefonicznie o rozpoczęciu akcji zajść majowych przez Piłsudskiego kierował się tym, że jako bliski człowiek Piłsudskiego powinienem być zawiadomiony o fakcie marszu. Ja na wiadomość o tym czułem się zobowiązany zameldować się u Piłsudskiego czy nie będę mu w tym momencie w czymś potrzebny.

\footnotetext{
${ }^{12}$ Wincenty Witos (1874-1945), polityk, jeden z przywódców ruchu ludowego, 1908-1914 poseł do Sejmu Krajowego, a 1911-1918 do austriackiej Rady Państwa. W latach 1914-1918 wiceprezes, następnie prezes PSL „Piast” (1918-1931). 1918-1919 przewodniczący Polskiej Komisji Likwidacyjnej. Poseł na Sejm RP w latach 1919-1930, trzykrotny premier (1920-1921, 1923, 1926). Po zamachu majowym jeden z przywódców antysanacyjnej opozycji, w 1930 r. więzień brzeski, w latach 1933-1939 na emigracji w Czechosłowacji. Od 1931 r. prezes Rady Naczelnej Stronnictwa Ludowego. Po 1939 r. internowany przez Niemców.

${ }_{13}$ Bolesław Wieniawa-Długoszowski (1881-1942), generał dywizji WP, polityk, dyplomata, jeden z najbliższych współpracowników Józefa Piłsudskiego. W okresie pierwszej wojny światowej w tzw. Pierwszej Kompanii Kadrowej, następnie w 1 Pułku Ułanów. Adiutant Piłsudskiego, w latach 1918-1919 uczestnik specjalnej misji wysłanej do Paryża w celu zawarcia porozumienia z Komitetem Narodowym Polskim. W latach 1921-1922 attaché wojskowy w Rumunii, w 1924 r. skierowany na kurs w Wyższej Szkole Wojennej. 1926-1930 dowódca 1 Pułku Szwoleżerów, w latach 1930-1938 na czele 1 Brygady, a następnie 2 Dywizji Kawalerii. 1938-1940 ambasador RP w Rzymie. W 1942 r. popełnił samobójstwo.
} 
Przy spotkaniu Piłsudski polecił mi udać się do Związku Zawodowego Kolejarzy i przedstawić mu potrzebę przeciwdziałania ze strony kolejarzy by oddziały transportowane do Warszawy dla obrony rządu Witosa napotkały na trudności transportowe ze strony kolejarzy. Chodziło przede wszystkim o oddziały mogące być przysłane z poznańskiego, które mogły zaostrzyć walki w Warszawie. Na polecenie Piłsudskiego udałem się do siedziby Zw. Zaw. Kol. i powtórzyłem zlecenie Piłsudskiego ówczesnemu sekretarzowi Zw. Zaw. Kolej. Kuryłowiczowi ${ }^{14}$ imienia nie znam który przyjął je do wiadomości i o ile wiem kolejarze zastosowali się w dniach majowych do tego polecenia. Kuryłowicz w tym czasie był członkiem P. P. S- $\mathrm{u}^{15}$.

W okresie walk ulicznych żadnych określonych funkcji nie miałem, a zdając sobie sprawę z ważności badania nastrojów panujących w takich wypadkach wśród ludności cywilnej z własnej inicjatywy starałem się je poznać. Przy nadarzających się w tym czasie bardzo krótkich zresztą rozmowach z Piłsudskim wyrażałem na ten temat swoje wrażenia.

Po zakończeniu walk ulicznych podczas wyboru nowego Prezydenta R. P. przez Zgromadzenie Narodowe byłem w kuluarach Sejmu celem dowiedzenia się jakie są nastroje w kołach sejmowych.

Ponieważ byłem na galerii sejmowej podczas posiedzenia Zgromadzenia Narodowego po ogłoszeniu wyników głosowania nad kandydaturą Piłsudskiego na Prezydenta R. P. zawiadomiłem go o rezultacie głosowania udając się do jego kwatery w Warszawie przy ul. Królewskiej. Wtedy Piłsudski zakomunikował mi że Ratajowi ${ }^{16}$ który przyjedzie zapytać się go o to czy przyjmuje urząd Prezydenta R. P. da odpowiedź odmowną. Jakie były pobudki działające u Piłsudskiego nie mówił mi. Wiadomość tą przeniosłem do kuluarów sejmowych jeszcze przed enuncjacją marszałka Rataja, że Piłsudski nie przyjął wyboru na urząd Prezydenta R. P. udając się do gmachu sejmowego dla obserwowania dalszego ciągu posiedzenia Zgromadzenia Narodowego. Po zakomunikowaniu przeze mnie tej wiadomości niektórym posłom wywołała ona poruszenie, a wśród posłów lewicy sejmowej niezadowolenie jak np. u posła Marka ${ }^{17}$ imienia nie przypominam sobie z P. P. S-u będącego adwoka-

${ }^{14}$ Adam Kuryłowicz (1890-1966), działacz robotniczy, polityk. Od 1909 r. w Polskiej Partii SocjalnoDemokratycznej Galicji i Śląska Cieszyńskiego. W latach 1914-1916 w armii austriackiej, następnie powrócił do Lwowa. Od 1920 do 1939 r. w Radzie Naczelnej PPS, 1928-1939 członek Centralnego Komitetu Wykonawczego tej partii. 1921-1937 przewodniczący Zarządu Głównego Związku Zawodowego Kolejarzy, a w latach 1928-1937 wiceprzewodniczący Komisji Centralnej Związków Zawodowych. Poseł na Sejm RP (1922-1930, 1934-1935). Po 1939 r. pozostał w Polsce.

${ }^{15}$ Polska Partia Socjalistyczna - powstała w 1892 r. w wyniku połączenia tzw. II Proletariatu, Związku Robotników Polskich, Zjednoczenia Robotniczego i Gminy Narodowo-Socjalistycznej. W 1893 r. doszło do rozłamu, w wyniku którego powstała Socjaldemokracja Królestwa Polskiego. W 1906 r. miał miejsce kolejny rozłam, tym razem na tle stosunku do niepodległości Polski — grupa działaczy stawiających tę kwestię na czołowym miejscu założyła PPS-Frakcję Rewolucyjną. W 1909 r. powrócono do dawnej nazwy. W okresie pierwszej wojny światowej i w pierwszych latach niepodległości ugrupowanie to popierało politykę Piłsudskiego, po zamachu majowym przeszło jednak stopniowo do opozycji. ${ }^{16}$ Maciej Rataj (1884-1940), polityk, w latach 1913-1918 w PSL „Piast”, od 1918 r. w PSL „Wyzwolenie”, a następnie ponownie w PSL „Piast”. 1921-1931 członek Rady Naczelnej tej partii i jeden z jej przywódców. W latach 1920-1921 minister wyznań religijnych i oświecenia publicznego. Poseł na Sejm w latach 1919-1930. W Sejmie I kadencji (1922-1928) sprawował funkcję marszałka izby, dwukrotnie pełniąc obowiązki głowy państwa (1922, 1926). W latach 1931-1939 członek Naczelnego Komitetu Wykonawczego Stronnictwa Ludowego, 1935-1939 prezes partii. Zamordowany przez Niemców w 1940 r.

${ }^{17}$ Zygmunt Marek (1872-1931), prawnik, polityk, w latach 1897-1919 członek Komitetu Wykonawczego PPSD. 1911-1918 poseł do austriackiej Rady Państwa. W okresie pierwszej wojny światowej 
tem w Krakowie. Wiadomość o w/w odmowie Piłsudskiego przeniosłem do kuluarów sejmowych z własnej inicjatywy, uważając ją za zupełnie pewną, która wkrótce będzie podana przez Rataja do wiadomości. Nie przypominam sobie bym w tych rozmowach wspomniał o wysuwanej przez Piłsudskiego kandydaturze na Prezydenta R. P. Ignacego Mościckiego ${ }^{18}$, o czym mogłem już wiedzieć z rozmowy z Piłsudskim. Po dokonaniu wyboru Mościckiego na Prezydenta R. P. zakomunikowałem niezwłocznie tę wiadomość Piłsudskiemu.

$\mathrm{Na}$ tym moja działalność w okresie wypadków majowych i w czasie wyboru nowego Prezydenta R. P. zakończyła się.

$[\ldots]$

w Naczelnym Komitecie Narodowym, jesienią 1917 r. po kryzysie przysięgowym bronił legionistów przed austriackim sądem. W 1918 r. członek Polskiej Komisji Likwidacyjnej, a od 1919 r. Komisji Rządzącej dla Galicji, Śląska, Spiszu i Orawy. Poseł na Sejm RP w latach 1919-1930. 1924-1926 członek Rady Naczelnej PPS, od 1928 r. prezes Centralnego Sądu Partyjnego. W 1928 r. wybrany na wicemarszałka Sejmu z ramienia PPS. Jesienią tego roku uległ atakowi apopleksji i częściowemu paraliżowi, co w praktyce uniemożliwiło mu dalszą działalność polityczną.

${ }^{18}$ Ignacy Mościcki (1867-1946), wybitny chemik, polityk, prezydent RP. W latach młodości związany z ruchem socjalistycznym. Od 1892 r. na emigracji, w 1894 r. poznał Józefa Piłsudskiego. Od 1897 r. w Szwajcarii, związał się z Uniwersytetem we Fryburgu. Autor licznych wynalazków (m.in. pozyskiwanie azotu z powietrza), w 1912 r. otrzymał katedrę chemii fizycznej i elektrochemii technicznej na Politechnice Lwowskiej. Od 1922 r. dyrektor zakładów azotowych w Chorzowie, w 1925 r. objął katedrę elektrochemii technicznej na Politechnice Warszawskiej. Założyciel Państwowych Zakładów Związków Azotowych w Tarnowie. Prezydent RP w latach 1926-1939. Po klęsce wrześniowej internowany w Rumunii, zmarł w 1946 r. w Szwajcarii. 